\title{
PUBLIC EQUALITY, PUBLIC REASON AND LIBERAL COMMUNITY
}

\author{
Nebojša Zelić \\ Department of Philosophy \\ University of Rijeka \\ E-mail: nzelic@ffri.hr
}

DOI: 10.20901/an.12.04

Prethodno priopćenje Primljeno: veljača 2016.

\begin{abstract}
In his The Constitution of Equality: Democratic Authority and its Limits Christiano defends an idea that democracy has authority because it realizes public equality. According to Christiano, for realization of public equality there is no need for any restriction on the content of reasons we offer each other to justify laws and policies. In this paper I try to show that there are good reasons to think that boundaries of public reason can more deeply realize public equality in plural society and I also try to defend this view from some criticisms given by Christiano in his book.
\end{abstract}

Keywords democracy, public reason, public equality, Thomas Christiano

It is a great privilege to have the opportunity to discuss Thomas Christiano's The Constitution of Equality: Democratic Authority and its Limits. ${ }^{1}$ It is certainly one of the most important theoretical accounts of democracy. But, it is not only a contribution to democratic theory, it is also a powerful defense of liberal -democracy and also a certain form of the welfare state. Christiano gives a very sophisticated account not only of democratic rights, but also of liberal rights and social minimum. The aim of my discussion is to try to emphasize certain points of his theory from an alternative approach to liberal democracy - politi-

1 Page references in parentheses refer to this book. cal liberalism. More particularly, from the central idea of political liberalism and its idea of public reason. I must apologize in advance that it would surely be an oversimplification of Christiano's account, which is very sophisticated and nuanced. I try first to find shared ground between Christiano's basic ideas and the Rawlsian idea of public reason. I then focus on providing some reasons for accepting the idea of public reason as a guideline in democratic deliberation, something which Christiano refutes. But, I try to present the case for public reason on the grounds of the notion of political community and what role deliberation, constrained by public reason, can play in constituting a political community in the circumstances of pluralism. 
The first problem that proponents of Rawlsian public reason can raise against Christiano's account of democracy and justice is that he grounds the intrinsic equality of human beings in the notion of dignity. Namely, if the purpose of society is to establish justice among persons then we must have a certain account of justice. For Christiano, justice is grounded in the equal dignity of persons, therefore it "demands that the well-being of each person be advanced equally or at least that all persons have available to them equal basic conditions for advancing their well-being" (4). Political liberals can say that dignity is philosophically too burdened a concept to be the foundational idea of justice in plural societies. We can imagine other plausible candidates for the foundation of justice, for example, pleasure. Political liberals can say that if we should apply the principle of tolerance to philosophy itself, as Rawls famously stated, than we cannot ground our account of justice in a philosophically controversial notion because it will be sectarian. The objection that political liberals can raise is not simply that an account of justice refers to some philosophically controversial concept like dignity. There will be many different grounds of justice or justifications of principles of justice and luckily they will converge. The problem to which political liberals can point to is that a stronger claim is made - that the only way to ground justice is in the value of dignity. In that case it seems that such an account of justice cannot be accepted by adherents to other comprehensive ethical views even though they could accept the content of the principles of justice, but on different grounds. We would then, enter into a foundational disagreement which, according to political liberals, is not appropriate for political dis- cussion in plural democracies. This would imply that in political discussion, when discussing what is legal or illegal, we should base our views on what is intrinsically valuable to human life by already having a correct account of what that is. In this case, life lived according to the value of dignity.

I do not think that this can serve as a worthy objection. Dignity, how Christiano employs the term, is not some kind of supreme value that must be promoted, but it is a status which ought to be honored. It is thus a status of equal dignity that is conferred on every human being on the basis of a certain capacity. This capacity is in Christiano's terms the value of humanity. Christiano writes, "The humanity of a person is that person's capacity to recognize, appreciate, engage with, harmonize with and produce intrinsic goods" (14). Humanity must also not be considered as the ground of all value, it just "connects human beings with the realm of value in the world" (14). It says, if I understand it correctly, that even if important part of humanity is the production of values in the world it does not mean that humanity is the source of all values. So, a religious person can believe that god is the source of values, but also accept humanity as a distinct way human beings engage with these values. Because human beings have this capacity they are "a kind of authority in the realm of value" (15). This authority gives them a special status in the world and sacrificing them for the sake of other intrinsic values implies a failure to acknowledge their status, a failure to acknowledge their equal dignity as beings who poses this capacity. It seems to me that there is nothing controversial in grounding dignity in such a capacity. If political liberals still hold 
that this is controversial then they also seem to have a problem of their own. Namely, many of them hold that the basis of equality is the moral capacity for the conception of good, which is the "capacity to form, revise and rationally pursue a conception of one's rational advantage of good" (Rawls, 1996, 19). ${ }^{2}$ Thus, if Christiano's grounding of equality in dignity or humanity is controversial or sectarian then grounding equality in the moral capacity for the conception of good is also sectarian. As a matter of fact, it was disputed by some philosophers that it assumes that one's conception of good carries normative force only if it has been the product of self-conscious, deliberate choice. ${ }^{3}$ But, this critique is wrong because what grounding equality in the moral capacity for good assumes is just what it says - we all have a capacity to engage with intrinsic goods and formulate our conception of a good life around these goods. It is not saying what these intrinsic goods are - autonomous life or life according to custom and tradition, for example. In the same sense, Christiano can answer potential objections to his notion of humanity, that it would be sectarian if he assumed or claimed that there is a particular specification of the content of intrinsic goods with which persons engage. Thus, it seems to me that Christiano's notion of humanity and Rawls's notion of the moral capacity of the conception for good are quite similar in their objective and also in their answer

2 There are of course two moral powers Rawls mentions. The other moral power is a capacity to understand, to apply, and to act from the public conception of justice.

3 For example by J. Donald Moon (Moon, 1993, 57). to possible critics. They are both uncontroversial because without them persons would not be able to have a conception of a good life, and also it is up to them to choose in what way they will engage with intrinsic goods, what these goods will be and how they will change their engagement with intrinsic goods as they live their lives. The way we engage with intrinsic goods and how successful we are in realizing them in our lives defines our well-being. Furthermore, equality as a basic principle of justice demands that each person's well-being should be advanced. But, if what I said so far makes sense, than it seems to me that it implies something to which I will return to in the discussion below, and that is the priority of the free exercise of reason. If our well-being is in important part defined by the way we engage with intrinsic goods, and it would certainly be overly paternalistic to say which intrinsic goods and which kind of engagement is appropriate, then it is left to our reason to figure this out. In a sense, the free exercise of reason must be respected even if we, through exercising it, come to different conclusions and accept a doctrine that does not give priority to the free exercise of reason.

The similarities between Christiano and political liberalism go further because they both strive for a general conception of liberal justice that can be used to arrange institutions. Political liberals accept the liberal principle of legitimacy: "Our exercise of political power is fully proper only when it is exercised in accordance with a constitution the essentials of which all citizens as free and equal may reasonably be expected to indorse in the light of principles and ideal acceptable to their common human reason (Rawls, 1996, 131). Thus, it says that 
constitutional essentials must be acceptable to common human reason. Constitutional essentials only give us a framework within which we should exercise our political power in democratic politics. And we can interpret this to mean that this framework must be built only by public reason. Within this framework we can exercise our political power without being constrained by the boundaries of public reason, as long as this exercise is in accordance with this framework. The content of this framework is the general liberal conception of justice, which is specified by three principles - first, it assigns citizens certain basic rights and liberties; second, it assigns those rights and liberties special priority; and, third, it provides citizens with adequate, all purpose means to make use of those rights and liberties (Ibid, xlviii-xlix). Certainly, citizens will disagree about which specific conception of liberal justice satisfies these general principles, and they will bring their laws and policies in accordance with the constraints these principles place. Also, even though these principles must be acceptable to common human reason, the justification of laws and policies within the framework of these principles does not have to be justified only by reasons acceptable to all, but it can instead be justified on more perfectionist reasons that are part of some particular set of values. Of course as long as it does not undermine one's exercise of basic rights and liberties.

It seems to me that Christiano's account of democracy can be interpreted along similar lines. The guiding principle of justice, according to Christiano is the principle of the equal advancement of interests. The permanent feature of society is that there will always be a con- flict of interests and disagreements about the common good and justice. Thus, the realization of justice or the equal advancement of interests in such circumstances must be the realization of the principle of public equality. It means that each citizen can see that she is treated as equal even though there is a permanent disagreement over laws and policies. Every citizen can see that she is treated according to the principle of public equality if their disagreements are resolved through democratic decisionmaking for which every citizen must have equal democratic rights. Also, in order to be able to equally advance their interests every citizen must have equal basic liberal rights such as freedom of consciousness, freedom of expression, freedom of association and freedom of pursuits. Furthermore, every citizen must have a guaranteed minimum of economic resources that enables her to exercise and enjoy these rights. Grounding all of these rights in the same principle - the principle of public equality implies that our exercise of political power through democratic decisionmaking cannot violate the basic liberal or economic rights of some portion of citizens or their democratic rights by, for example, disenfranchising them. Christiano even gives the role to a certain judiciary body, such as a high court, to strike down legislation if it violates such rights because it is the violation of public equality. Thus, even though the democratic assembly, where we exercise our democratic rights, has authority, this authority is constrained by public equality. Christiano is clear that "for a state to be authoritative, it must be reasonably just either in the substance of its laws or in the process by which it makes those laws" (236). Realizing public equality through these three sets of rights (demo- 
cratic, liberal and economic) ensures that the state will be reasonably just, at least to a certain minimum. Of course, citizens will disagree on more substantive conceptions of justice but this minimal requirement of justice should be "the point in the theory where disagreement no longer has the power to legitimate an outcome of collective decision-making" (269). Those who reject public equality or its implications for democracy "should know better and the society is not required to respect these antiegalitarian judgments in the sense that it must accept as legitimate decisions that are grounded in this antiegalitarian judgment" (269). I believe we can say that the principle of public equality is an ideal acceptable to common human reason. ${ }^{4}$ And I believe we can say that the principle of public equality demands all three features of the general liberal conception of justice - it requires assigning basic democratic and liberal rights, gives them priority over other considerations that can occur in democratic decision-making, and it also provides all purpose means to make use of those rights and liberties in the form of an economic minimum. And, also within this framework citizens can enjoy wide democratic discretion in reaching democratic decisions by appealing to different ideas of the common good and specific conceptions of justice which are compatible with the general conception of liberal justice. It seems to me that we can

4 I believe this is clear because in the background of principle of public equality are our fundamental interests we have independently of our particular understanding of good. These interests are: interest in correcting for cognitive bias; interest at being at home in the world; interest in being treated as a person with equal moral standing among one's fellow citizens $(60-63)$. say that public reason can take a form of public equality. We can say that this is public reason as public equality. What can seem to be the most problematic aspect of this interpretation is that the second requirement - giving special priority to rights - is not fully compatible with a whole approach of Christiano's project, given that he does not insist on such a clear difference between the political and the comprehensive conceptions of justice as political liberals do. Namely, it can imply that only special kind of reasons, those backed by the political values on which rights are based, can play a justificatory role in democratic assembly. This is the view I will defend below, but this is not the sole plausible interpretation of public reason. We can say that we only give special priority to rights when certain political issues are put and formulated in the terms of basic rights. It seems clear to me that Christiano accepts this position. He does not only say that we all have formally equal liberal rights, but that we should not be unduly burdened in exercising these rights even if it is for good reason. "For example, in many cases" Christiano explains "one may not require the Catholic Church in the United States to comply with laws banning discrimination on the basis of sex even though discrimination on the basis of sex is thought to be wrong and is banned in the case of many economic activities" (134). Or for example, urban planning or zoning are usually under the discretion of local government decision-making. They can bring regulations under which some places of public worship cannot be built or ruled out altogether. But, if this decision is challenged by referring to the freedom of religion than this right has priority and it cannot be overridden by certain perfectionist or esthetic reasons even if 
those reasons would be perfectly fine if not challenged by liberal right. ${ }^{5} \mathrm{I}$ believe Christiano would agree that our democratic rights, liberal rights and democratic procedures should be in the constitution. ${ }^{6}$ Thus, it seems to me that our exercise of political power when in accordance with the constitution is our exercise of political power that is in accordance with the principle of public equality. One possible problem is the provision of an economic minimum. The United States, for example, does not have any social rights in its constitution, but most other well-established democracies contain such rights in their constitutions. So, I take it that even a certain minimum of economic and material rights should be in the constitution.

But, according to Christiano, public equality stops at this level. This is the last point where, according to Christiano, equality can be public. To go further it would enter into the domain of disagreements on controversial conceptions of justice and equality, disagreements that should be subject of democratic decision-making. The outcomes of democratic decision-making and the reasons we give for our political proposals do not have to satisfy the same requirement of publicity as the principle of public equality does. Thus, the realization of public equality does not require any constraint on our reason giving or justification for proposals. The liberal principle of legiti-

5 At least, this is how I understand Christiano when he says that „if a zoning regulation rules out public places of worship, without being explicitly designed to rule them out, such a regulation seems to be a violation of freedom of religion as well“" (139).

6 It does not have to be written constitution but that it has place that rights and democratic procedures have in written constitutions. macy on the interpretation given above also does not go that far, but stops at the same level as public equality. Public equality realized at that level also grounds democratic authority. Democratic decision-making embodied in a democratic assembly has the authority because it realizes the principle of public equality. Outcomes of such decisionmaking do not have to fully satisfy justice to be authoritative. They can be less just than one's favorite conception of substantive justice would demand, but democratic assembly still has the moral power to demand obedience from a citizen and the citizen still has the moral obligaion to obey the law. In that sense citizens have content-independent reasons to obey democratic decisions. Content-dependency comes into light only in cases when these decisions violate those rights that realize public equality or, as we said above, when they violate the general liberal conception of justice. Thus, a democratic assembly that satisfies public equality has the authority as a right to rule that "includes the liberty on the part of the authority to make decisions as it sees fit and it includes a power to impose duties on citizens" (241). Citizens have a moral duty to obey the democratic assembly because this political institution embodies public equality. This gives inherent authority to democratic assembly, which is different from instrumental authority that government agencies have. In a democracy government agencies and courts derive their authority from finding ways of specifying and achieving the aims of democratic assembly.

But, what seems important to me is what this inherent authority, according to Christiano, adds to what was previously considered to be merely a political aggregate of individuals who by exercis- 
ing their liberal rights associate with like-minded others and make narrow moral communities based on their more particular values. Inherent authority has important role in constituting one political community. As Christiano says, it "describe[s] a kind of ideal of political community" (242). Reason for this is that it is "grounded in a moral relationship between the parties that goes beyond the fact that they are fellow human beings...The exercise of political power is founded in a moral relationship between moral persons that recognizes and affirms the moral personality of each citizen" (242).

This notion of community and moral relationship is particularly important for the possible argument that the idea of public reason can serve as a constraint on the appropriate political argument within political deliberation and not only as an idea of public equality. It can refer to a more common notion of how political liberals specify the idea of public reason - as a constraint on legitimate reasons for political decisions. But, let's first see what we can learn about political community from Christiano's usage of the notion of inherent authority as a right to rule. He makes it clear that "society ruled by an authority that has the right to rule is an ideal of a moral community, the other types of authority are lesser forms of morally ideal political community" (243). Other types of authority such as instrumental authority cannot be the core ideal of a political community. Our moral relationship, which is constitutive of community, stems out of our duty to respect the principle of public equality, but only through its embodiment in democratic assembly. Thus, it is not that our duty is simply grounded in public equality and then according to some true standard of pub- lic equality someone can make decisions in our name and demand our obedience by simply saying that we owe duty to these laws because we already have a duty to act according to the principle of public equality. Someone who would do that would place himself "and his judgment above that of others in a way that a parent places her judgment above that of an infant or a god places its judgment over that of human being" (235). In reaching our political decisions we must take care of what others think and more particularly what they say. Thus, if inherent authority is grounded in public equality and it is constitutive of the ideal of moral community, then deliberation is also constitutive of moral community. In that sense deliberation is within the reach of the principle of public equality. We can see this clearly when Christiano argues against equal lotteries or another random choosing device that respects fairness for choosing among political proposals. Democracy is better than such devices because it realizes equality more adequately than lotteries. Thus, the point is that in the model of lotteries, even though it is fair, equality is satisfied only at the moment before the lottery, and after that moment there is no further reach of equality. In an ordinary democracy equality extends to voting, campaigning, representing, and of course to the process of democratic deliberation. Democratic authority that is grounded in public equality includes deliberation because we must extend public equality as far as it can reach. Thus, political community is constituted by the inherent authority of democratic assembly that features democratic deliberation as a necessary component. This is important if we are going to conceptualize community not in terms of the same culture or identity, which is prob- 
lematic because of deep disagreements on these issues, but in terms of common institutions and our relationship within these institutions. We can say that democratic deliberation shapes our relationship within shared political institutions. In a sense this implies that equality realized in our deliberation constitutes the nature of our political relationship making it a relationship of equals.

I do think that equality realized in deliberation defines and constitutes our moral relationship as members of one community, but I am not sure that the purely distributive account of equality that Christiano offers can fulfill the role that deliberation in democratic assembly is supposed to provide. The way I understand Christiano, equality is realized in the equal distribution of rights as a means of realizing that our fundamental interests should be equally respected. And this is also why deliberation is an indispensable part of democracy. Even when he discusses equality within deliberation Christiano still speaks about distribution: "the distribution of cognitive conditions for the effective exercise of citizenship, the distribution of opportunities for influencing the agenda of collective decision-making, and equality of respect that citizens hold for each other" (197). The first two considerations argue in favor of the availability of information and political skills, well designed institutions for civic participation within a representative democratic system, and policies that remove the power of money from political decision-making. The third consideration is different and it depends on the attitudes of persons toward each other, I will discuss that below. But, I have a worry that a purely distributive approach to equality cannot explain our relationship as inherently moral and give account of the ideal po- litical community. All these aspects can be supervised by some imagined political body that safeguards our rights if our political outcomes violate democratic rights and procedures, liberal rights and provision of an economic minimum, and which prescribes policies that provide the necessary means to exercise effectively our citizenship and the egalitarian public financing of parties. Still our political behavior can be strategic within these guarded limits. Should we consider any group of persons constrained in this way to constitute a community by themselves and their engagement with each other as moral engagement? Would we not also question how they make decisions and on what grounds? It seems to me that there must be some set of values that defines community and on which persons within that community act so we can say that their engagement with each other is a moral relationship. Of course, Christiano is right that we cannot have any specification of distributive equality that goes further into our political decision-making because we will plausibly disagree on it. I do, however, believe that equality, not in its distributive but in its relational aspect can be realized in the content of deliberation and that this also defines how we relate to each other.

The overall picture I have in mind is that when we justify institutions designed to promote democratic deliberation in plural societies we should appeal only to distributional equality, but when we give account of how this deliberation should be practiced to be the basis of community then we appeal to the relational aspect of equality. I believe that the idea of public reason as a constraint of reasons in our democratic deliberation provides this relational aspect of equality. As Rawls says, public reason 
changes the nature of our political relationship. ${ }^{7}$ In this interpretation, public reason it is not only a standard by which we evaluate procedures, laws and policies but, and with equal importance, also a set of guidelines as to how we should exercise our political power. More specifically, it can be seen as a guide on how to practice our deliberation. It is the practice that demands that we consider each other as equals beyond having equal rights with which we enter into the political domain. But, what is the content of this practice of equality? Scheffler, for example, says that in "a relationship that is conducted on a footing of equality, each person accepts that the other person's equally important interests should play equally significant role in influencing decisions made within the context of relationship" (Scheffler, 2015, 25). He calls this requirement "the egalitarian deliberative constrai" (ibid.). The important thing is that Scheffler applies egalitarian deliberative constraint to private and political relationships. In private relationships it is easier to know what the interests of the other party are, and it is easier to weigh them in mutual discussion. Also, it is easier to see which decisions fall within the context of a relationship and which decisions should be externalized. If decisions are externalized then parties do not have to take the interests of others in the same way as they do when decisions fall within the context of a relationship. But, nevertheless, it is not so hard to see how it can be applied to a political relationship. Decisions that are within our core liberal rights are decisions that are outside the

7 Rawls writes that "the role of criterion of reciprocity as specified by public reason is to specify the nature of the political relation in a constitutional democratic regime as one of civic friendship" (Rawls, 1996, li). context of a political relationship, while decisions that are about our common political world are within this context. The context of a political relationship with which we are interested in here is a context where we as citizens deliberate not on any kind of decisions but on binding decisions. Decisions being made within this context are ones that we as citizens must obey and we can be sanctioned if we do not obey them. Of course, an additional element is that outcomes must be within the framework of liberal justice. Thus, interests that should be equally important are those interests that are compatible with liberal justice. More specifically, these are interests in realizing the values of liberal justice. It is possible that many persons will feel a strong attachment to values from their narrower moral communities, but these values are outside the context of our relationship as citizens. They are within the context of their associations. When I speak of the values of liberal justice I have in mind values such as freedom, equality, fairness, cooperation and fact of burdens of judgments. ${ }^{8}$ Also, saying that interests in these values should play an equally significant role means that they should be weighed against each other and that interests in values that are outside of this set cannot outweigh these values. I believe these values are compatible with public equality in the sense that I do not see how a citizen who adheres to the principle of public equality can propose political outcomes that will be in contrast with these values. This simply says that a citizen who wholeheartedly adheres to the idea that the distribution of rights and the design of procedures must treat

8 This idea is more fully elaborated by Jonathan Quong in Quong (2011, ch.6). 
everyone as equals, cannot propose laws or policies that will be in contrast with the idea that citizens are free and equal in the sense that they are free to form their conception of the good and that this should be equally respected; also that she respects the fact of reasonable pluralism, and that she does not think that benefits and burdens should be distributed in fair terms where everyone can see herself as member of cooperation.

But, still these values do not say which laws or policies should be enacted or which reasons are to be considered as public reasons before the deliberation. It is part of the process of democratic deliberation to try to articulate our reasons in context of these values and weighing them. This interpretation of public reason requires that citizens accord a deliberative priority to those reasons that apply only to political values when they are discussing binding decisions. They will of course disagree about decisions, about which reason better justifies a decision, which value carries more weight on particular issues and which decision is more justified. But, by giving deliberative priority to reasons presented in terms of political values, they guarantee that they will give equal weight to the set of values they all share as citizens, and that majority will not have power simply to base decisions on the values and reasons that place the interests of some association, no matter how numerous, above others. Thus, the main point of this proposition is that a certain notion of equality can go further into the political sphere. Namely, it can go further into the content of political deliberation on decisions.

It seems to me that the idea of a community is important for this argument. For some group of individuals to form a community something must be shared.
It can not simply be an aggregation of individuals and their private desires. As Rawls says, well-ordered democracy is not a 'private society' in which institutional arrangements are purely of instrumental value for individuals in pursuit of their private ends (Rawls, 1999, 457). For political society to form a community there must be something that is shared among individuals and this fact must be manifested in their relationship. This set of shared ideals in plural liberal democracies is the set of political values that define liberal democracy, and our relation, constitutive of such a community, is the relation of us as citizens and not of us as adherents to particular doctrines or associations. It is of equal importance that we manifest this relation in a certain context. The appropriate context for such a relation is the context of deliberative decision-making where we make decisions that will bind all citizens. Manifesting our acceptance of these political values is also a crucial aspect of assurance that everyone will stick to these values even if they become the majority that can bring decisions that will violate our rights or make policies that will burden our exercise of liberal rights. In this way we truly constitute a political community through democratic assembly and empower it with an inherent authority without the need for any kind of high court that safeguards our political behavior. A high court, no matter how well justified, is always an agency added to cooperation while democratic assembly if constituted appropriately is a part of our political cooperation. ${ }^{9}$

Constraining argumentation in democratic assembly by public reason is

9 This is not an argument against an institution like a high court. I am just saying that we should try to give account of community without having in mind this institution. 
certainly what Christiano calls a narrow conception of public deliberation defined as the requirement that "citizens must advance proposals and the arguments for them only on the basis of the shared fund of political ideas" (191). Christiano contrasts this conception with a conception he favors, a wider conception of public deliberation according to which "citizens debate and discuss proposals for legislation and policy on the basis of arguments grounded in differing conceptions of justice and the common good and in different empirically grounded ideas about how society works" (190). What is important to note in first place is that the narrow view of deliberation I defend above, also allows arguments grounded in differing conceptions of justice as long as these conceptions are part of the general conception of liberal justice. But, certainly its constraints appeal to controversial doctrines and ideas of the common good based solely on these doctrines. It seems, or at least I understand it that way, that the wide conception of deliberation allows such reasons and proposals, if they aim rationally, to persuade others, and if persons proposing such reasons accept the force of a better argument. This wide conception of deliberation embodies many fundamental values - equal respect, commitment to advancing justice and the common good; the public realization of equality. The narrow conception of deliberation, Christiano says, adds to these values a principle of reasonableness or reciprocity. This is certainly correct, but as I claimed above, it seems to me that the narrow conception can be argued for in terms of relational equality as constitutive of community. Nevertheless, it is clear that manifestation of such a notion of equality is made through respecting the principle of reasonableness.
Specifying these two conceptions of deliberation is not problematic for the view I endorse. On the contrary, to contain both of these conceptions in different domains of deliberation can serve as a valuable goal in democratic society. But, Christiano confronts these two conceptions by saying that democracy can endorse either the wide conception or the narrow conception and he gives powerful arguments for refuting the narrow conception. His arguments against the narrow conception or more specifically, against the requirement of reasonableness as the demand that citizens should appeal only to reasons that can be accepted by all are directed against three kinds of arguments for reasonableness - epistemic, moral and democratic. His critique of two kinds of arguments - epistemic and democratic - I can accept without endangering the position outlined above. I do not think epistemic considerations should be arguments for public reason, and I do not think that not respecting the boundaries of public reason violates democracy or makes someone a second-class citizen. But, refuting the moral argument in the way Christiano does presents a fatal blow to any position of that kind if plausible. Thus, I will focus only on the moral argument.

Christiano presents his moral argument for reasonableness in three steps: "First, everyone must respect each person's free exercise of her own reason. Second, in order to respect the free exercise of each person's reason, one must respect the products of her reason, in particular her reasonable comprehensive doctrines. Third, in order to respect the products of each person's reason, one must not require her to live in ways that are incompatible with their reasonable comprehensive doctrine" (215-216). 
Christiano then presents two fatal dilemmas for this argument. The first dilemma says "that the argument from respect for reason either implies controversial comprehensive doctrine or does not support the principle of reasonableness." The second dilemma says "that the argument either implies a need for complete consensus or fails to establish the principle of reasonableness" (216). Let's first focus on first dilemma. According to Christiano, this argument presupposes a lexical superiority of respect for the free exercise of reason over other values, for example over epistemic values of a certain doctrine. Christiano then claims that " $(t)$ he idea that the value of the free exercise of reason is lexically superior to all other values is a highly controversial claim" (217). Thus, by the standard of reasonableness it is not reasonable. The second part of the dilemma is equally problematic because "if the reasonable person takes account of differences in the epistemic reasonableness of comprehensive doctrines in establishing terms of association, then, the reasonable person ought to advance the most reasonable conception of value that she has" (218). But, I do not see why the demand for the priority of the free exercise of reason should be considered controversial. To see this we should recall the problem we discussed at the beginning of the paper. The basis of equality is our equal dignity conferred on us because we have a capacity to engage with an intrinsic good, which Christiano calls humanity. For many people the intrinsic good is articulated in the comprehensive doctrines to which they adhere. Many citizens will engage with intrinsic goods through some comprehensive doctrine - moral, philosophical or religious. At least, we are supposed to imagine that things will go that way. We have to make room for people to be committed to their comprehensive doctrines as well as to liberal justice. What this argument tells us is that we should not devise terms of associations that can make their adherence to their reasonable comprehensive doctrine harder solely on the grounds of other reasonable comprehensive doctrine. Respecting products of one's reason does not mean that reason produces all the values, but simply that someone's acceptance of certain values or comprehensive doctrine is the product of the free exercise of reason. It simply means that we should not promote a certain reasonable, comprehensive doctrine through our power as the authors of laws. Maybe I do not understand well what it would mean to give priority to epistemic values over the free exercise of public reason, but it seems to me that there can be clear cases where epistemic values can endanger the free exercise of reason if we use them, I repeat, as the authors of laws. For example, should we epistemically question the Christian doctrine of the Trinity that many think is really irrational or the doctrine of God's grace that says that grace is not based upon any reason at all, and yet it must be acknowledged to be just? Even though many can argue that these doctrines are on epistemically really shaky ground, persons must still be free to follow them. It seems to me that it would be inappropriate to invoke the irrationality or rationality of such doctrines in our deliberation on laws and policies.

We can now see the second dilemma Christiano presents for reasonableness. The second dilemma says that either we need a complete consensus on principles of justice or reasonableness fails. Why do we need a complete consensus on principles of justice? Because according 
to Christiano if "it is disrespectful to someone's reason in requiring him or her to live in accordance to principles he or she does not accept" then it is also "disrespectful of this proponent's reason to require her to forgo living in accordance with principles she reasonably accepts (i.e., to forgo living in accordance with the whole truth as she sees it)" (218). Thus, the situation is symmetrical. If I propose a principle I hold to be just, but others reasonably reject it, and they accept the principle I reasonably reject, then I must live with the terms of association that I reasonably regard as unjust. This situation Christiano calls a deliberative impasse - "Either one must impose on one person terms that she does not accept or one must require another to live accordingly under terms that he regards as fundamentally inadequate" (219). Again, the solution to this situation is to invoke the epistemic reasons and thus the requirement of reasonableness fails. But, my worry here is that I do not see this symmetry, and therefore I do not see the situation of a deliberative impasse. There is a difference between the criteria of reasonable rejection and reasonable acceptance. So, according to the view I embrace no one can reasonably reject the general conception of justice or public equality. But the general conception of justice contains a family of liberal conceptions of justice characterized by a set of political values. Proposals within this set presented in terms of political values are those that reasonable persons reasonably accept even though they do not hold that all of them equally just. Every proposal within this set that the majority votes for is reasonably acceptable to everyone. So, I do not see how anyone can hold this proposal as fundamentally inadequate or fundamentally unjust even though she reason- ably rejects it in favor of another proposal. On the other hand, if the person holds this particular proposal as fundamentally inadequate on the basis of her reasons coming from her comprehensive doctrine, then she is appealing to reasons that are part of a different kind of disagreement to influence a political decision that is in the domain of another kind of disagreement. The first kind of disagreement is a disagreement at the fundamental level about the good life, where no common evaluative standard exists in plural societies, while the second kind of disagreement is a narrower political disagreement where there is supposed to be a common standard of liberal justice and political values. A person who disregards this is violating the requirement of reciprocity and is placing her interests above the interests of others. Let us look at an example of this in the debate on the public financing of stem-cell research. Research in stem-cell biology gives us well supported hope that we will be able to heal people with serious cardiovascular or neurological issues. On the other hand, this research includes the in vitro fertilization of a human egg and destroying it (in the form of a blastocyst) three to five days later. Current Catholic doctrine opposes such research because they believe that the blastocyst is ensouled from the moment of conception and has equal normative moral status as any other human person. According to the view defended here, if the debate on financing stem-cell research takes place in a public political forum then it must be within the boundaries of public reason, and the justification of financing such research must be based on public reasons or political values. The demand for health or the demand for the normal development of capabilities and the avoidance of disabil- 
ity cannot be dismissed as irrelevant for questions of justice as certain tastes and preferences often are. These demands can be understood as the reasonable demands for goods that every person needs to be able to form, revise and rationally pursue its rational plan of life or as part of political value of fair equality of opportunity. On the other hand, belief in ensoulment can be translated in the political value of due protection of human life, which is an important value that we can expect every reasonable citizen to accept. So, the debate can be within the boundaries of public reason. Thus, the decision to stop stem-cell research would mean giving excessive weight to the due respect we owe human life in contrast to the weight of some primary goods or the fair equality of opportunity. To justify the special weight assigned to the due respect for human life in this context, would bring in a nonpublic value or belief that a blastocyst has a non-overridable right to life from the moment of conception. This belief about the moral status of blastocyst is not a belief that all reasonable citizens accept. It would be wrong to deprive people of some good or diminish a certain political value on the basis of the belief that we cannot reasonably expect what these persons can accept. So, the reason why the belief in ensoulment is not considered to be public reason is because it cannot be a shared reason in a pluralistic society and not because it is not, for example, evidentially supported or because it is epistemologically flawed.

If the decision were to be made on the grounds of such a belief than it would imply that we give more weight to an interest that is not in the set of shared interests of our political community, and that we give more weight to values of one of particular community existing in society. On the other hand, when the person who holds the belief in ensoulment at the moment of conception loses in a political discussion constrained by political values, she cannot say that some other narrow moral community won. What happened is that the majority holds that some values, which she also accepts, carry more weight in the political community of which she is also a part as a reasonable citizen. It seems to me that these two cases are not symmetrical. Of course stem-cell research is one of the hard cases. We can imagine many other cases that can be more easily presented in terms of political values. Christiano's example is the choice of the principle of the distribution of employment. There are many principles for the distribution of employment - according to desert, efficiency or the maximization of the economic position of the least advantaged. All of these three principles can be presented by referring to political values only - which principle, for example better satisfies the freedom of occupation, social cooperation or fairness. They can include a discussion, for example, on how fair it is that someone was luckier to have marketable talents; or if desert is a necessary part of considering citizens freedom to choose their occupation; how will the principle of desert or efficiency distribute burdens and benefits on the least-advantaged if they are considered to be participants of social cooperation. Then there can be debate on empirical grounds for certain claims or propositions. Therefore, if the person who regards the desert-based approach as fully just, loses in the political game because the majority votes for principle of efficiency. For example, she lost on the basis of the political values she accepts as a citizen of liberal democracy. She cannot say that any principle chosen in this way is fully unjust. 
This is not an argument against every possible situation of a deliberative impasse. An impasse can occur because, for example, which solution presents the best balance of political values will be indeterminate, and the problem can be presented solely in terms of political values. There are number of ways to deal with this situation, and I will not discuss them here. ${ }^{10} \mathrm{I}$ just want to argue that it is not so likely that the situation of a deliberative impasse will occur simply according to citizens' deliberative priority towards political values and public reasons.

The aim of this discussion about the moral argument for reasonableness is only to show that the narrow conception of deliberation is feasible and not incoherent. The aim is not to defend the narrow conception of deliberation over the wide conception of deliberation. Contrary to Christiano, I do not think that these two conceptions of deliberation exclude each other. We do not have to choose between two ideas of democracy - one that is reasonable or narrow and one that is open to various other grounds for argumentation or wide. I do not see a problem of having an idea of a democratic society where these two conceptions of deliberation apply to different spheres. One, narrow conception, applies to a particular sphere of democratic society - the narrowly political sphere that includes deliberation will necessarily end with binding political decision. The second, wider conception, refers to the wider notion of democratic society where we engage in deliberation with others, discuss political or nonpolitical issues that do not necessarily end with

10 This problem is discussed by Andrew Williams (2000), Micah Schwartzman (2004) and Elvio Baccarini (2015, ch. 1). the enforcement of the outcome of our decision. This wider deliberation includes citizen debates, opinion journalism, political art, expressions of various kinds, and many other activities oriented towards rationally persuading others in the correctness or truth of one's view. Of course, it is hard to divide informal political deliberation and formal political deliberation, but it is also hard to deny that this division exists. Political speeches to a wider audience from state officials, or political advertising in campaigns are gray areas, but nevertheless the official decision-making of legislators that results in laws is certainly the clearest example of narrow political deliberation, which is outside of this informal political sphere. In this informal political sphere we certainly need more open discussion and argumentation on other grounds than in formal political discussion. Every comprehensive view must be open and possibly scrutinized in order for basic interests of the individuals to be advanced. These basic interests are: "the interest in correcting for cognitive bias, the interest in being at home in the world, the interest in learning the truth, and the interest in being recognized and affirmed as equal" (200). In order to advance these interests, especially the first three, individuals must be free from any constraint except the willingness to listen to others and to reply to others. ${ }^{11}$ In this sphere they can question each other's doctrines on epistemic grounds. For example, in the issue of stem-cell research raised above, this domain is the appropriate domain for questioning the epistemic reasonableness of the doctrine of ensoulment at the

11 There can also be certain restrictions of time, place and manner of speech. Also, many countries have regulations about hate speech. 
moment of conception. Here we can, for example, describe a mechanism of early human ontogeny in enough detail to raise puzzles about the exact stage at which "ensoulment" must occur. ${ }^{12}$ We can question this belief also from historic grounds. This belief occurred in $17^{\text {th }}$ century when fertilized ova appeared through primitive microscopes to resemble perfectly formed people. According to Aquinas' teaching, the soul enters when the human shape is formed. Thus, the conclusion was that it happens at the moment of fertilization. ${ }^{13}$ But, as our understanding of human embryology progressed, scientists began to realize that this view of fetal development was wrong. The Catholic Church, however, never abandoned its policy, although it is based on empirically flawed data. This can clearly be an argument used in the debate among citizens. But at the formal political level there is no need to trespass on each other's doctrines in this way.

But why would this sphere be important if it is through laws and policies that citizens arrange their common world? Well, the point is that it is not only through laws and policies that our common social world is arranged. Our common world and the society we share is in important ways also arranged by how our co-citizens use their liberal rights, what associations they make and how they express their adherence to their conceptions of the good or comprehensive doctrines. Christiano also says that “(l)iberal rights give people the power to

12 This argument is presented by Phillip Kitcher in (Kitcher, 2011, 235).

13 This history of belief in insoulment from the moment of conception is taken from James Rachels in (Rachels, 2003, 61). St. Thomas Aquinas thought that embryo does not have a soul untill few weeks into pregnancy because then fertilized ova gets human shape. organize their relations with other people and thereby give them some power over other people" (134). Thereby, it is not so clear that liberal rights confer power on people to shape only their individual lives because by arranging their private lives and the lives of their associations they clearly arrange the common world and the society we all share. It influences the environment and atmosphere in which we will live our lives. Society can in this way, for example, be and look religious without in any official and governmental sense being religious by state sponsored religions. A certain kind of traditional ethos can prevail and appear in everyday life without being prescribed by law or promoted by certain policies. And if this is the case then I do not see why this same kind of particular values should also be promoted by official legislation. By demanding the narrow conception of deliberation in the formal, political sphere of direct lawmaking we realize a public good of assurance in that the laws we make will be the expression of the liberal conception of justice and not the expression of others' opinion on our comprehensive doctrine or the lives we lead. It is the informal sphere where we are expected to say these kinds of judgments on each other, and every democratic society welcomes this sphere to be vibrant and lively. Particularly, if we allow the freedom of expression, which besides rational argument also includes ridiculing, intentional blasphemy and the expression of anti egalitarian attitudes, then it is clear why the formal political sphere should be a sphere which will assure us that laws will not be based on such premises.

When I talk about an assurance of this kind I believe it is also connected to the legitimacy of democratic assembly. Democratic assembly according to 
Christiano is properly constituted when "the representatives in the assembly have been elected in the proper way in a process of election that includes all sane permanent adult residents of the society" (246). It is the most important part of representative or electoral democracy and it further requires "a system of party list proportional representation coupled with an egalitarian system of financing of political parties and an egalitarian process of discussion among the different interest groups and pressure groups in the society" (246). So, if the democratic assembly is properly constituted then all citizens have the rights to an equal say and they have an institutional method by which they exercise these rights. This confers to democratic assembly a legitimate authority as a right to rule. Also, as we saw, it constitutes a political community. It is certainly true that a properly constituted democratic assembly fulfills this role, and I agree that representative democracy is the best way to realize public equality in large scale, plural societies. But, there are many empirical findings that put doubt on the belief that input side and fair procedures are the main pillars for creating political legitimacy. Bo Rothstein, for example, reports a paradox that trust in representative democratic institutions is decreasing in well-established, peaceful and rich democracies like the Scandinavian countries, but that still people accept the legitimacy of its laws. ${ }^{14}$ Part of the answer is that citizens are able to differentiate between the representation and the implementation side of the democratic system. The level of trust is higher when it comes to the so called implementation side of politics than is the

14 Rothstein discusses this issue in Rothstein (2011, ch. 4). case with the representational side. Also, what is surprising is that persistent cultural minorities in many EU countries (Swedish-speaking minority in Finland, German-speaking minority in Denmark) who do not believe they will ever prevail in some future elections, have higher levels of trust in their governments than national or linguistic majorities. Now, I am not saying that we can make some big conclusions from these reports. Primarily because the social sciences use different notions of legitimacy referring to the popular support of laws and institutions while political philosophers refer to legitimacy in its normative meaning. But nevertheless it can speak in favor of the view that holds that for legitimate authority it is not enough to ensure only equal rights, equal say and fair procedures to give legitimate authority. It can speak in favor of the need to give an account of a further element for legitimacy, and that is on what basis political decisions are made. Namely, if a number of citizens see themselves primarily as addressees of laws and have doubts that they are truly the authors of laws then we must have a set of values on which those laws are grounded that we expect citizens as addressees would accept. Laws are still made in their name. Public reason as a narrow conception of deliberation provides an assurance that even if democratic assemblies are not perfectly constituted they will still have outcomes that when implemented will be a realization of the values that citizens as the addresses of these laws can be reasonably expected to accept. If the trust in institutions strengthens norms of civic trust then public reason helps to strengthen these ties and make our political community more stable. 


\section{REFERENCES:}

Baccarini, E. (2015) In a Better World? Public Reason and Biotechnologies. Rijeka: University of Rijeka.

Christiano, T. (2008) The Constitution of Equality: Democratic Authority and its Limits. Oxford: Oxford University Press.

Kitcher, P. (2011) Science in Democratic Society. New York: Prometheus Books. Moon, J. D. (1993) Constructing Community. Princeton: Princeton University Press.

Quong, J. (2011) Liberalism without Perfection. Oxford: Oxford University Press.

Rachels, J. (2003) The Elements of Moral Philosophy. New York: McGraw-Hill.

Rawls, J. (1996) Political Liberalism. New York: Columbia University Press.
Rawls, J (1999) A Theory of Justice. Revised edition. Cambridge, Mass: Harvard University Press.

Rothstein, Bo (2011) The Quality of Government: Corruption, Social Trust and Inequality in International Perspective. Chicago: The Chicago University Press.

Scheffler, Samuel (2015) The Practice of Equality, in: C. Fourie, F. Schuppert, I. Wallimann - Helmer (eds.) Social Equality: On What It Means to Be Equals. Oxford: Oxford University Press.

Schwartzman, M. (2004) The Completeness of Public Reason. Politics, Philosophy and Economics 3 (2): 191-220.

Williams, A. (2000) The Alleged Incompleteness of Public Reason. Res Publica 6 (2): 199-211.

\section{Javna jednakost, javni um i liberalna zajednica}

SAŽETAK U svojoj knjizi The Constitution of Equality: Democratic Authority and its Limits Christiano brani gledište da demokracija ima autoritet zato jer ostvaruje javnu jednakost. Za realiziranje javne jednakosti, prema Christianu, nije potrebno nikakvo ograničenje koje se odnosi na sadržaj razloga koje nudimo jedni drugima kada opravdavamo zakone i javne politke. $U$ ovom članku pokušavam pokazati da postoje dobri razlozi zašto ograničenja javnog uma mogu doprinijeti dubljoj realizaciji javne jednakosti u pluralnom društvu te također pokušavam obraniti to gledište od nekih kritika koje je ponudio Christiano u svojoj knjizi.

KLJUČNE RIJEČI demokracija, javni um, javna jednakost, Thomas Christiano 